\title{
Surgery for Crohn's Disease: New Developments
}

\author{
T.J.Gardenbroek P.J.Tanis C.J. Buskens W.A. Bemelman \\ Department of Surgery, Academic Medical Center, Amsterdam, The Netherlands
}

\section{Key Words}

Crohn's disease $\cdot$ Surgery $\cdot$ SILS $\cdot$ Proctectomy

\begin{abstract}
Background/Aims: Crohn's disease is a chronic relapsing inflammatory bowel disease requiring surgery in a large number of patients. This review describes new developments in surgical techniques for treating Crohn's disease. Results: Single-incision laparoscopic surgery decreases abdominal wall trauma by reducing the number of abdominal incisions, possibly improving postoperative results in terms of pain and cosmetics. The resected specimen can be extracted through the single-incision site or the future stoma site. Another option is to use natural orifices for extraction (i.e. transcolonic/transanal), but actual benefits of these procedures have not yet been determined. In patients with extensive perianal disease or rectal involvement, transperineal completion proctectomy is often feasible, thereby avoiding relaparotomy. By using a close rectal intersphincteric resection, damage to the pelvic autonomic nerves is avoided. In addition, the risk of presacral abscess formation is reduced by leaving the mesorectal tissue behind. Conclusion: Minimally invasive surgery and associated techniques have become standard clinical practice in surgical treatment of patients with Crohn's disease. New developments aim at further reducing the hospital stay and morbidity, and improving the cosmetic outcomes.

Copyright ๑ 2012 S. Karger AG, Basel
\end{abstract}

\section{Introduction}

Crohn's disease is a chronic inflammatory bowel disease that can affect the entire gastrointestinal tract. It is a relapsing disease with large variability in clinical presentation. The incidence of Crohn's disease is 5-10 per 100,000 people per year [1]. The initial therapy consists of medical treatment. Despite the current variety of available medications, between 70 and $90 \%$ of patients with Crohn's disease will require surgery during their lifetime $[2,3]$, and nearly half of these patients will undergo repeat surgical interventions $[4,5]$. Indications for surgery are complications (acute or chronic), refractory disease despite optimal medical therapy, and side effects of medical therapy. Often, the initial presentation of Crohn's disease is early in life. Especially young patients and patients undergoing repeat surgery may benefit from bowel-sparing techniques and minimally invasive surgery with reduced adhesion formation. This review describes new developments in surgical techniques aiming at minimizing sequelae of surgical intervention in patients with Crohn's disease.

\section{Single-Incision Laparoscopic Surgery}

Laparoscopic techniques have transformed colorectal surgery in the last decades, and meanwhile numer-

\section{KARGER \\ Fax +41613061234 \\ E-Mail karger@karger.ch}

www.karger.com
(C) 2012 S. Karger AG, Basel

$0253-4886 / 12 / 0294-0275 \$ 38.00 / 0$

Accessible online at: www.karger.com/dsu
W.A. Bemelman

Academic Medical Center, Department of Surgery, G4-146.

PO Box 22660

NL-1100 DD Amsterdam (The Netherlands)

Tel. +3120 5666818, E-Mail w.a.bemelman@amc.uva.nl 

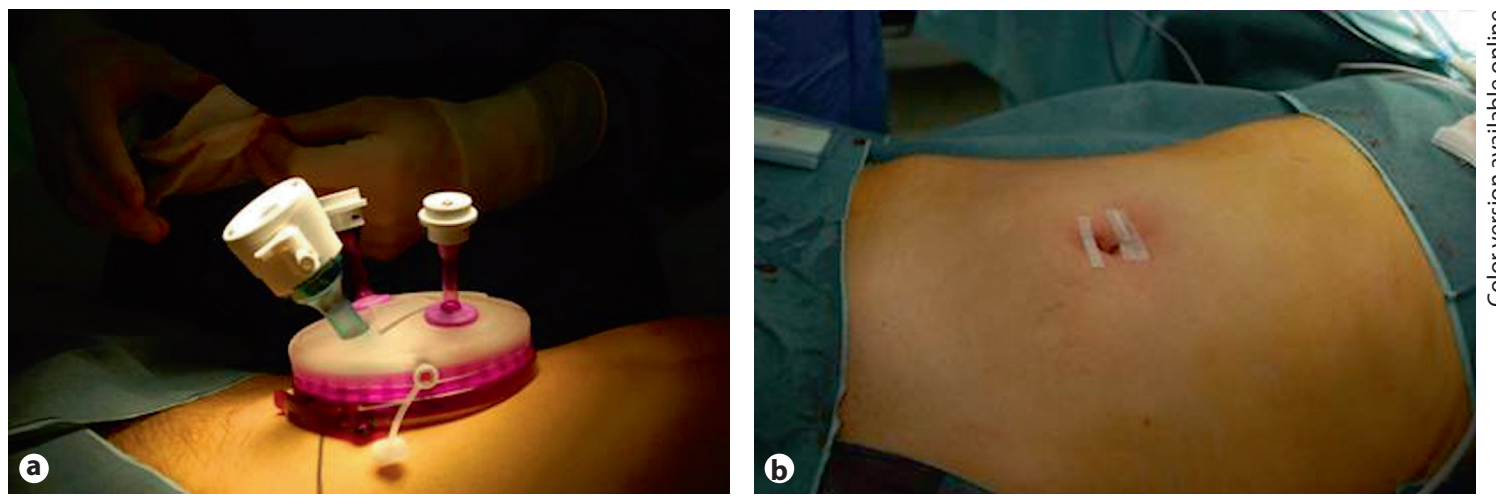

Fig. 1. a Single port placed at the level of the umbilicus during single-port ileocolic resection. b Postoperative result after single-port ileocolic resection. The incisional scar virtually disappears in the shallow of the umbilicus.

ous studies have shown the safety and advantages of laparoscopic surgery in Crohn's disease with reduced hospital stays, shorter times to first postoperative bowel movements, lower complication rates, better cosmetic outcomes and comparable disease recurrence rates for laparoscopic and open surgery [6-14]. In our opinion, the laparoscopic approach is preferable in patients with inflammatory bowel disease.

Single-incision laparoscopic surgery (SILS) is a promising new development in the field of minimally invasive surgery. This technique has been developed to decrease abdominal wall trauma further by reducing the number of abdominal incisions compared with the standard laparoscopic approach. This might decrease postoperative pain, shorten the recovery period and improve cosmesis. SILS has already been applied in ileocolic resections, right and left hemicolectomies, total colectomies, sigmoid resections and restorative proctocolectomies [1529]. In SILS, the umbilicus is most frequently used as the only access site through which the specimen is dissected and extracted. The scar virtually disappears in the shallow of the umbilicus (fig. 1a, b). In benign disease, close pericolic dissection of the mesocolic and omental attachments of the colon can be performed, thereby facilitating specimen removal through the small incision. In patients who will have an ostomy, the SILS port can be placed at the ostomy site.

Crohn's disease limited to the ileocolic region is a common indication for laparoscopic surgery. The SILS ileocolic resection has recently been described by Rijcken et al. [30] for medically refractory stenosis of the terminal ileum in 20 consecutive patients. A matched comparison was performed with patients who underwent standard laparoscopic ileocolic resection. There were no differences in conversion rates (1/20 in the SILS group vs. $2 / 20$ in the standard laparoscopic group). Similar major complication rates $(2 / 20$ in the SILS group vs. $1 / 20$ in the standard laparoscopic group) and wound infection rates (2/20 in both groups) were reported. No differences in the postoperative pain scores, length of peridural anesthesia or hospital stay were found. This study showed that the SILS ileocolic resection is feasible, safe and effective with the advantage of having less port sites and superior cosmesis although the latter was not formally studied.

SILS has also been described for ileocolic resections in complex Crohn's disease with previous surgery, fistulas and abscesses. Most reports describe single cases [3134]; however, one study reported a consecutive series of 6 patients with abscesses, phlegmons or enterocutaneous fistulae [35]. There were no conversions to laparotomy, but 4 of 6 patients required diversion with a loop ileostomy. In all of these patients, the ileostomy site was used for placement of a single-site port. Mean operative time was $160 \mathrm{~min}$ and the median length of the hospital stay was 3 days. No 30-day readmissions or mortality has been reported in this study. These studies show that the benefits of the standard laparoscopic ileocolic resection are preserved in the SILS approach; the superiority of the SILS approach in improving postoperative results in terms of pain and cosmetics has yet to be proven.

SILS colectomy has also been described as a feasible and safe technique in a review article by Leblanc et al. [22]. The review included 9 studies with a total of $17 \mathrm{pa}-$ tients and reported a mean operative time of $116 \mathrm{~min}$, a mean hospital stay of 5 days and a mean final scar length 
Table 1. Overview of advantages and disadvantages of the different specimen extraction techniques

\begin{tabular}{|c|c|c|c|}
\hline $\begin{array}{l}\text { Laparoscopic } \\
\text { techniques }\end{array}$ & $\begin{array}{l}\text { Specimen } \\
\text { extraction site }\end{array}$ & $\begin{array}{l}\text { Advantages } \\
\text { of extraction site }\end{array}$ & $\begin{array}{l}\text { Disadvantages of } \\
\text { extraction site }\end{array}$ \\
\hline $\begin{array}{l}\text { Hand-assisted } \\
\text { laparoscopic } \\
\text { surgery }\end{array}$ & Pfannenstiel & $\begin{array}{l}\text { tactile feedback } \\
\text { visibility }\end{array}$ & $\begin{array}{l}\text { suprapubic scar } \\
\text { incisional hernia }\end{array}$ \\
\hline \multirow{3}{*}{$\begin{array}{l}\text { Total } \\
\text { laparoscopic } \\
\text { surgery }\end{array}$} & trocar port incision & $\begin{array}{l}\text { extraction of large } \\
\text { specimen possible }\end{array}$ & $\begin{array}{l}\text { large port site incision } \\
\text { incisional hernia }\end{array}$ \\
\hline & Pfannenstiel & $\begin{array}{l}\text { extraction of large } \\
\text { specimen possible }\end{array}$ & $\begin{array}{l}\text { suprapubic scar } \\
\text { incisional hernia }\end{array}$ \\
\hline & transanal & $\begin{array}{l}\text { no additional scar } \\
\text { possible reduction of } \\
\text { adhesions and incisional } \\
\text { hernia }\end{array}$ & $\begin{array}{l}\text { intra-abdominal infectious } \\
\text { complications } \\
\text { technically difficult } \\
\text { extraction of large specimen } \\
\text { not possible }\end{array}$ \\
\hline \multirow[t]{2}{*}{$\begin{array}{l}\text { Single incision } \\
\text { laparoscopic } \\
\text { surgery }\end{array}$} & umbilicus & $\begin{array}{l}\text { reduction in port sites } \\
\text { cosmetics; scar disappears } \\
\text { in shallow of umbilicus }\end{array}$ & $\begin{array}{l}\text { technically difficult } \\
\text { extraction of large specimen } \\
\text { not possible }\end{array}$ \\
\hline & stoma site & no additional incisions & parastomal hernia \\
\hline
\end{tabular}

of $31 \mathrm{~mm}$. A series of 10 consecutive patients with inflammatory bowel disease undergoing (sub)acute emergency colectomy included 3 patients with Crohn's disease [29]. All 3 (emergency) laparoscopic colectomies were safe and feasible. However, larger series with specific data on SILS colectomy in patients with Crohn's disease are needed to verify the benefits of this procedure.

The safety of a new technique is an important issue if its application on a larger scale is considered. SILS is probably more difficult than conventional laparoscopy because triangulation is hampered. In addition, ergonomics are decreased due to the parallel insertion of the instruments. Therefore advanced laparoscopic skills and case selection are essential to minimize the risk of technique-related complications. The learning curve of the SILS procedures has not been described in patients with Crohn's disease. However, in SILS cholecystecomies and SILS ileocolic resections, several studies showed that the learning curve does not include the slow beginning and steep acceleration seen in standard multi-incision laparoscopy [27, 36, 37]. In SILS colectomy, a minimal learning curve in experienced laparoscopic surgeons is described [28, 38]. New developments in the design of the SILS instruments and robotics in combination with SILS might overcome these issues in the future.

Surgery for Crohn's Disease: New

Developments

\section{Specimen Extraction Techniques}

Removal of the specimen from the peritoneal cavity requires an incision. Several different techniques have been developed to extract the colonic specimen with no or minimal additional surgical trauma to the abdominal wall, such as the previously mentioned SILS technique or the natural-orifice specimen extraction techniques (table 1). For removal of the colonic specimen after resection of a T1 tumor, endometriosis or ulcerative colitis, extraction of the specimen through the rectum has been described [39-42]. Since bowel mobilization, dissection, transsection and creation of the anastomosis can be done by using a total laparoscopic approach, removal of the specimen is the only reason to extend one of the port incisions or to create a Pfannenstiel incision in a patient with Crohn's disease. Especially in patients with benign disease in whom close colonic dissection is sufficient and no large inflammatory mass is present, the specimen can be exteriorized through the anus. This technique has been successfully applied after total laparoscopic ileocolic resection [43] and after laparoscopic colectomy [29] for Crohn's disease. The study of Eshuis et al. [8] included 10 patients with ileocolic Crohn's disease. Nine patients underwent primary resection and 1 patient underwent resection of the neoterminal ileum. The ileocolic specimen was retrieved by 


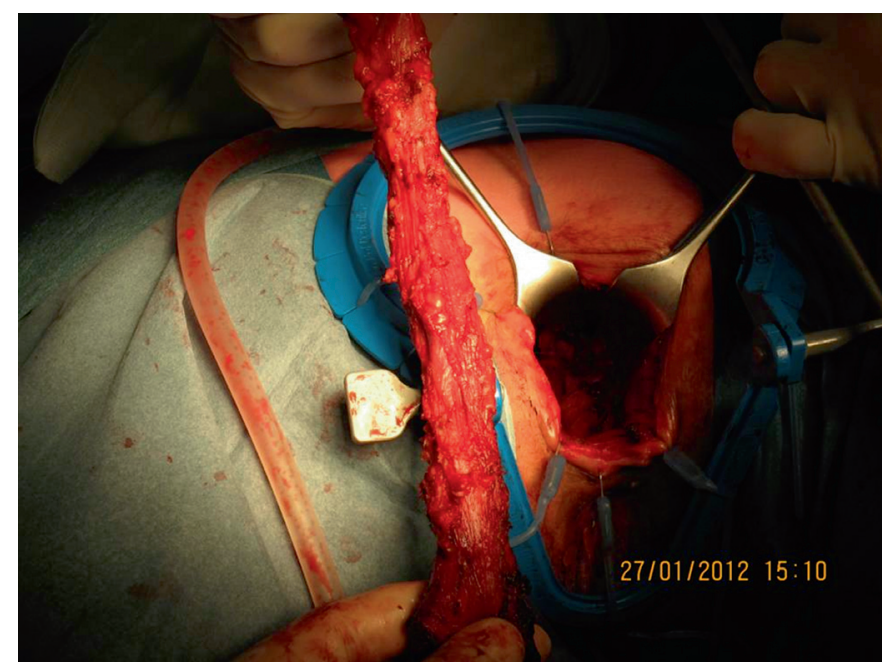

Fig. 2. Intersphincteric resection of the rectum performed exclusively via a transperineal approach with a large rectosigmoidal stump after close rectal resection.

an endoscopist through the uncompleted anastomosis and ultimately exteriorized through the anus. Transcolonic specimen removal was feasible in 8 out of 10 patients. The data of patients that underwent transcolonic specimen removal were compared to previously published data for laparoscopically assisted ileocolic resection. The results demonstrated a longer operating time in the transcolonic group (208 vs. $115 \mathrm{~min}$ ) but a comparable length of hospital stay (5 days) for both techniques. No differences in pain scores or quality of life, body image and cosmesis were found between the two groups. In another study from our institution, 10 consecutive patients with inflammatory bowel disease that underwent laparoscopic (sub)acute emergency colectomy with extraction of the colectomy specimen through the anus or stoma site were described. This series included 3 patients with Crohn's disease. In 1 of these patients, the colectomy specimen was successfully extracted transanally after laparoscopic subtotal colectomy, with no infectious complications or reoperations.

Transstomal extraction of the colectomy specimen can be used in patients with a previously constructed ileostomy by placement of a balloon trocar or SILS port at the ileostomy site. This technique was used in 2 patients with Crohn's disease in this study [29].

These studies show the technical feasibility and safety of the different specimen extraction procedures. However, the actual benefits of these procedures have not been determined. The possible advantages of standard laparoscopic resection in the reduction of adhesions and incisional hernias in the long term have to be shown in larger series with longer follow-ups. Furthermore, the procedures are technically difficult and require a skilled team for their successful completion. The extraction can be complex in case of a large colonic tumor, a specimen with thickened mesentery or an en-bloc specimen with omentum or abdominal wall. From an oncological point of view, excessive manipulation of the specimen may induce tumor spillage. In transcolonic and transanal specimen removal, the anastomotic staple line is opened for a considerable period of time to facilitate specimen removal, which increases the possibility of fecal contamination, resulting in intra-abdominal infections or abscesses. Therefore, complicated extraction techniques with the avoidance of a minilaparotomy are expected to be predominantly useful if no future (mini)laparotomy is required, for instance in restorative procedures.

\section{Transperineal Completion Proctectomy}

In patients with extensive perianal disease and rectal involvement, where both medical management and (local) surgical treatment failed, the first surgical option is a defunctioning colostomy. If that does not provide sufficient relief, the 'last resort' option is completion proctectomy. Around $10-20 \%$ of patients with perianal Crohn's disease ultimately undergo completion proctectomy $[44,45]$.

When proctectomy is opted for, either a low Hartmann's procedure or a transperineal intersphincteric resection of the rectum can be performed. A low Hartmann's procedure is defined as an anterior resection with total mesorectal excision, in which the rectum is stapled at the dentate line or within the last centimeters of the lower rectum. A disadvantage of the low Hartmann's procedure is the residual distal rectal mucosa. This can cause persisting complaints of Crohn's disease and anastomotic breakdown will result in a presacral abscess draining and fistulizing through the perineum [46-49]. Therefore, the intersphincteric resection procedure is preferred in our center. This procedure usually comprises two consecutive phases: an abdominal and a perineal phase. However, the procedure can often be performed exclusively via a transperineal approach, with the patient in prone position. Using ultrasonic dissection, it is very feasible to dissect the rectum in a close rectal manner. With adequate hemostasis and retraction, rectosigmoidal stumps of up to $25 \mathrm{~cm}$ can be safely resected using a transperineal approach, thereby precluding an abdominal phase (fig. 2). Another advantage of the close rectal 


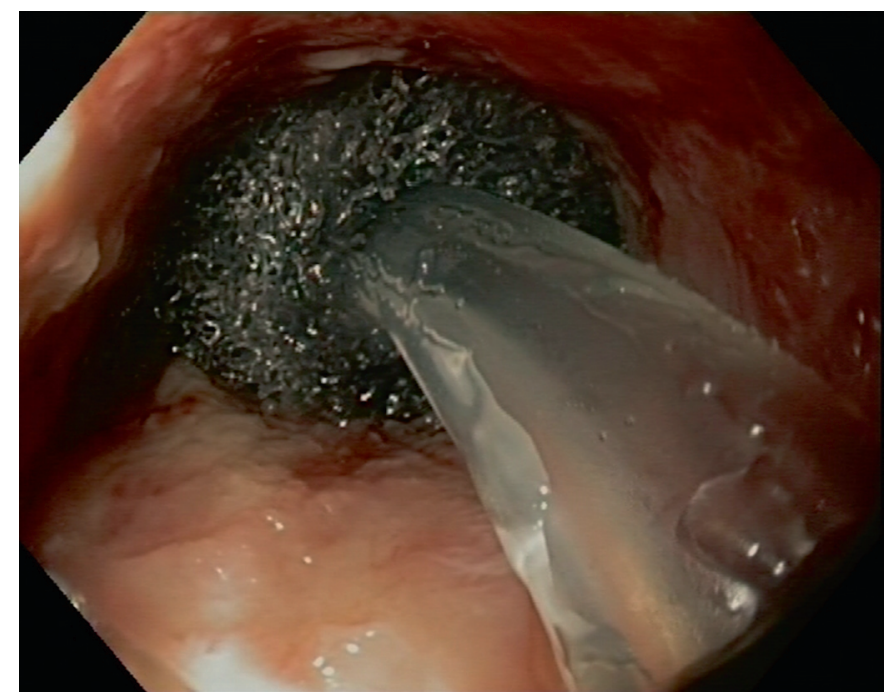

Fig. 3. Vacuum-assisted drainage of the pelvic cavity after proctectomy.

technique is preservation of the rectal mesentery, leaving only a minimal cavity. This not only reduces the risk of subsequent abscess formation due to natural filling of the presacral space, but it also avoids damage to the pelvic autonomic nerves.

Known complications of completion proctectomy or proctocolectomy for Crohn's disease are poor perineal wound healing and a persistent presacral sinus, with
$\stackrel{\Xi}{\underline{\Xi}}$ an incidence of around $40 \%$ after proctectomy $[50,51]$. Possible contributing factors to the cause of the perineal sinus are postoperative perineal or pelvic infection and failure to fill the pelvic cavity or perineal space with pelvic organs or adjacent musculoskeletal structures. The remaining cavity can be cleaned using vacuum-assisted drainage techniques with endosponge (fig. 3). The subatmospheric pressure drains the excessive fluid from the extravascular space, thereby improving the local blood flow and oxygenation [52]. The size of the remaining cavity is limited by using the close rectal dissection technique and leaving the mesorectal tissue behind, and preexisting sepsis can be treated effectively by applying the endosponge. After endosponge-assisted drainage of the perineal sepsis and stimulation of granulation tissue, the cavity can be closed surgically by suturing the external anal sphincter.

\section{Conclusion}

In the surgical treatment of patients with Crohn's disease, minimally invasive surgery is currently recognized as standard treatment. New developments derived from existing minimal invasive techniques are SILS, naturalorifice specimen extraction, close rectal dissection techniques and transperineal resectional surgery, all aiming at further reducing surgical trauma.

\section{References}

$\checkmark 1$ Carter MJ, Lobo AJ, Travis SP: Guidelines for the management of inflammatory bowel disease in adults. Gut 2004;53(suppl 5): V1-V16.

$>2$ Baumgart DC, Sandborn WJ: Inflammatory boweldisease: clinical aspects and established and evolving therapies. Lancet 2007;369: 1641-1657.

$>3$ Louis E, Collard A, Oger AF, Degroote E, Aboul Nasr El Yafi FA, Belaiche J: Behaviour of Crohn's disease according to the Vienna classification: changing pattern over the course of the disease. Gut 2001;49:777-782.

$\checkmark 4$ Duepree HJ, Senagore AJ, Delaney CP, Brady KM, Fazio VW: Advantages of laparoscopic resection for ileocecal Crohn's disease. Dis Colon Rectum 2002;45:605-610.

$>5$ Bernell O, Lapidus A, Hellers G: Risk factors for surgery and postoperative recurrence in Crohn's disease. Ann Surg 2000;231:38-45.
-6 Polle SW, Wind J, Ubbink DT, Hommes DW, Gouma DJ, Bemelman WA: Short-term outcomes after laparoscopic ileocolic resection for Crohn's disease. A systematic review. Dig Surg 2006;23:346-357.

7 Dasari BV, McKay D, Gardiner K: Laparoscopic versus open surgery for small bowel Crohn's disease. Cochrane Database Syst Rev 2011;1:CD006956.

$>8$ Eshuis EJ, Polle SW, Slors JF, Hommes DW, Sprangers MA, Gouma DJ, Bemelman WA: Long-term surgical recurrence, morbidity, quality of life, and body image of laparoscopic-assisted vs. open ileocolic resection for Crohn's disease: a comparative study. Dis Colon Rectum 2008;51:858-867.

$\checkmark 9$ Rosman AS, Melis M, Fichera A: Meta-analysis of trials comparing laparoscopic and open surgery for Crohn's disease. Surg Endosc 2005;19:1549-1555.
10 Tilney HS, Constantinides VA, Heriot AG, Nicolaou M, Athanasiou T, Ziprin P, Darzi AW, Tekkis PP: Comparison of laparoscopic and open ileocecal resection for Crohn's disease: a meta-analysis. Surg Endosc 2006;20: 1036-1044.

11 Tan JJ, Tjandra JJ: Laparoscopic surgery for Crohn's disease: a meta-analysis. Dis Colon Rectum 2007;50:576-585

12 Maartense S, Dunker MS, Slors JF, Cuesta MA, Pierik EG, Gouma DJ, Hommes DW, Sprangers MA, Bemelman WA: Laparoscopic-assisted versus open ileocolic resection for Crohn's disease: a randomized trial. Ann Surg 2006;243:143-149.

13 Eshuis EJ, Slors JF, Stokkers PC, Sprangers MA, Ubbink DT, Cuesta MA, Pierik EG, Bemelman WA: Long-term outcomes following laparoscopically assisted versus open ileocolic resection for Crohn's disease. Br J Surg 2010;97:563-568. 
14 Polle SW, Bemelman WA: Surgery insight: minimally invasive surgery for IBD. Nat Clin Pract Gastroenterol Hepatol 2007;4:324-335.

$\checkmark 15$ Bucher P, Pugin F, Morel P: Single port access laparoscopic right hemicolectomy. Int J Colorectal Dis 2008;23:1013-1016.

- 16 Adair J, Gromski MA, Lim RB, Nagle D: Single-incision laparoscopic right colectomy: experience with 17 consecutive cases and comparison with multiport laparoscopic right colectomy. Dis Colon Rectum 2010;53: 1549-1554.

17 Boni L, Dionigi G, Cassinotti E, Di GM, Diurni M, Rausei S, Cantore F, Dionigi R: Single incision laparoscopic right colectomy. Surg Endosc 2010;24:3233-3236.

18 Bucher P, Pugin F, Morel P: Transumbilical single incision laparoscopic sigmoidectomy for benign disease. Colorectal Dis 2010;12: 61-65.

19 Chen WT, Chang SC, Chiang HC, Lo WY, Jeng LB, Wu C, Ke TW: Single-incision laparoscopic versus conventional laparoscopic right hemicolectomy: a comparison of shortterm surgical results. Surg Endosc 2011;25: 1887-1892.

-20 Geisler DP, Condon ET, Remzi FH: Single incision laparoscopic total proctocolectomy with ileopouch anal anastomosis. Colorectal Dis 2010;12:941-943.

- 21 Katsuno G, Fukunaga M, Nagakari K, Yoshikawa S, Ouchi M, Hirasaki Y: Single-incision laparoscopic colectomy for colon cancer: early experience with 31 cases. Dis Colon Rectum 2011;54:705-710.

-22 Leblanc F, Champagne BJ, Augestad KM, Stein SL, Marderstein E, Reynolds HL, Delaney CP: Single incision laparoscopic colectomy: technical aspects, feasibility, and expected benefits. Diagn Ther Endosc 2010; 2010:913216. Epub May 30.

23 McNally ME, Todd MB, Brown KM: Singleincision laparoscopic colectomy for malignant disease. Surg Endosc 2011;25:3559-3565.

24 Remzi FH, Kirat HT, Kaouk JH, Geisler DP: Single-port laparoscopy in colorectal surgery. Colorectal Dis 2008;10:823-826.

-25 Rieger NA, Lam FF: Single-incision laparoscopically assisted colectomy using standard laparoscopic instrumentation. Surg Endosc 2010;24:888-890.

-26 Vestweber B, Alfes A, Paul C, Haaf F, Vestweber KH: Single-incision laparoscopic surgery: a promising approach to sigmoidectomy for diverticular disease. Surg Endosc 2010;24:3225-3228.

-27 Waters JA, Guzman MJ, Fajardo AD, Selzer DJ, Wiebke EA, Robb BW, George VV: Single-port laparoscopic right hemicolectomy: a safe alternative to conventional laparoscopy. Dis Colon Rectum 2010;53:1467-1472.
28 Papaconstantinou HT, Sharp N, Thomas JS: Single-incision laparoscopic right colectomy: a case-matched comparison with standard laparoscopic and hand-assisted laparoscopic techniques. J Am Coll Surg 2011;213:72-80.

-29 Gardenbroek TJ, Eshuis EJ, van Acker GJ, Tanis PJ, Bemelman WA: Alternative specimen extraction techniques after laparoscopic emergency colectomy in inflammatory bowel disease. Surg Endosc 2012;26: 408-412.

30 Rijcken E, Mennigen R, Argyris I, Senninger N, Bruewer M: Single-incision laparoscopic surgery for ileocolic resection in Crohn's disease. Dis Colon Rectum 2012;55: 140-146.

31 Heeney A, O'Connor DB, Martin S, Winter DC: Single-port access laparoscopic surgery for complex Crohn's disease. Inflamm Bowel Dis 2010;16:1273-1274.

32 Scaringi S, Giudici F, Liscia G, Cenci C, Tonelli F: Single-port laparoscopic access for Crohn's disease complicated by enterocutaneous fistula. Inflamm Bowel Dis 2011;17: E6-E7.

33 Gaujoux S, Bretagnol F, Ferron M, Panis Y: Single-incision laparoscopic colonic surgery. Colorectal Dis 2011;13:1066-1071.

34 Chaudhary B, Glancy D, Dixon AR: Laparoscopic surgery for recurrent ileocolic Crohn's disease is as safe and effective as primary resection. Colorectal Dis 2011;13:1413-1416.

- 35 Stewart DB, Messaris E: Early experience with single-site laparoscopic surgery for complicated ileocolic Crohn's disease at a tertiary-referral center. Surg Endosc 2012;26: 777-782.

-36 Hernandez J, Ross S, Morton C, McFarlin K, Dahal S, Golkar F, Albrink M, Rosemurgy A: The learning curve of laparoendoscopic single-site (LESS) cholecystectomy: definable, short, and safe. J Am Coll Surg 2010;211: 652-657.

- 37 Ma J, Cassera MA, Spaun GO, Hammill CW, Hansen PD, Aliabadi-Wahle S: Randomized controlled trial comparing single-port laparoscopic cholecystectomy and four-port laparoscopic cholecystectomy. Ann Surg 2011; 254:22-27.

38 Huscher CG, Mingoli A, Sgarzini G, Mereu A, Binda B, Brachini G, Trombetta S: Standard laparoscopic versus single-incision laparoscopic colectomy for cancer: early results of a randomized prospective study. Am J Surg 2012;204:115-120.

39 Larson DW, Dozois E, Sandborn WJ, Cima R: Total laparoscopic proctocolectomy with Brooke ileostomy: a novel incisionless surgical treatment for patients with ulcerative colitis. Surg Endosc 2005;19:1284-1287.
40 Whiteford MH, Denk PM, Swanstrom LL: Feasibility of radical sigmoid colectomy performed as natural orifice translumenal endoscopic surgery (NOTES) using transanal endoscopic microsurgery. Surg Endosc 2007; 21:1870-1874.

41 Wexner SD: Restorative proctectomy with colon pouch-anal anastomosis by laparoscopic transanal pull-through: an available option for low rectal cancer? Surg Endosc 2007;21:1679.

42 Levitt MA, Martin CA, Falcone RA Jr, Pena A: Transanal rectosigmoid resection for severe intractable idiopathic constipation. J Pediatr Surg 2009;44:1285-1290.

43 Eshuis EJ, Voermans RP, Stokkers PC, van Berge Henegouwen MI, Fockens P, Bemelman WA: Laparoscopic resection with transcolonic specimen extraction for ileocaecal Crohn's disease. Br J Surg 2010;97:569-574.

44 Basu A, Wexner SD: Perianal Crohn's disease. Curr Treat Options Gastroenterol 2002;5: 197-206.

45 Williamson PR, Hellinger MD, Larach SW, Ferrara A: Twenty-year review of the surgical management of perianal Crohn's disease. Dis Colon Rectum 1995;38:389-392.

-46 Bernell O, Lapidus A, Hellers G: Recurrence after colectomy in Crohn's colitis. Dis Colon Rectum 2001;44:647-654.

-47 Lock MR, Fazio VW, Farmer RG, Jagelman DG, Lavery IC, Weakley FL: Proximal recurrence and the fate of the rectum following excisional surgery for Crohn's disease of the large bowel. Ann Surg 1981;194:754-760.

-48 Stern HS, Goldberg SM, Rothenberger DA, Nivatvongs S, Schottler J, Christenson C, Nemer F, Balcos E: Segmental versus total colectomy for large bowel Crohn's disease. World J Surg 1984;8:118-122.

\$9 Guillem JG, Roberts PL, Murray JJ, Coller JA, Veidenheimer MC, Schoetz DJ Jr: Factors predictive of persistent or recurrent Crohn's disease in excluded rectal segments. Dis Colon Rectum 1992;35:768-772.

50 Yamamoto T, Bain IM, Allan RN, Keighley MR: Persistent perineal sinus after proctocolectomy for Crohn's disease. Dis Colon Rectum 1999;42:96-101.

51 Maeda Y, Heyckendorff-Diebold T, Tei TM, Lundby L, Buntzen S: Gracilis muscle transposition for complex fistula and persistent nonhealing sinus in perianal Crohn's disease. Inflamm Bowel Dis 2011;17:583-589.

52 Schaffzin DM, Douglas JM, Stahl TJ, Smith LE: Vacuum-assisted closure of complex perineal wounds. Dis Colon Rectum 2004;47: 1745-1748. 